\title{
Effect of Performance Expectation, Social Influence, and Self-Confidence on the Mobile Learning Behavior
}

\author{
(A Study on Bachelor Degree Students of Economic Education Program of \\ Universitas Terbuka)
}

\author{
Rhini Fatmasari \\ Universitas Terbuka \\ Jakarta, Indonesia \\ riens@ecampus.ut.ac.id
}

Dewi Gunherani

Universitas Pamulang

Jakarta, Jakarta

dgunherani@ojk.go.id

\author{
Erni Murniarti \\ Universitas Kristen Indonesia \\ Jakarta, Indonesia \\ Erni.murniarti@uki.ac.id
}

\author{
Donna Sampaleng \\ Sekolah Tinggi Theologi IKAT \\ Jakarta, Indonesia \\ sttetmpb@gmail.com
}

\author{
Diyah Yuli Sugiarti \\ Universitas Islam 45 \\ Jakarta, Indonesia \\ diyah.ys@gmail.com
}

\begin{abstract}
This study aimed to examine the effect of UTAUT (Unified Theory of Acceptance and Use of Technology) on the use of M-Learning by bachelor degree students of Economic Education program of Universitas Terbuka (UT). M-learning is a flexible learning mode that utilizes smart phone or PDA as learning media. The success of M-learning depends on their interest to continue to use the system. Users will feel satisfied and motivated to continuously use the information system if they feel that it gives the great output. This study used a model with three variables, i.e. performance expectation, social influence. Participants of this study were 148 bachelor degree students of Universitas Terbuka's Economic Education program. The results of the study showed that: (1) there was a significant correlation between the performance expectation after using M-learning with the intention to use M-learning on the students, (2) there was a significant correlation between the social influence in using M-learning with the intention to use M-learning on the students; (3) there was a significant correlation between the self-confidence in using M-learning with the intention to use M-learning on the students; and (4) there was not a significant and positive correlation between the intention to use M-learning with the Mlearning usage behavior.
\end{abstract}

Keywords-UTAUT; M-learning; Universitas Terbuka's Economic Education program

\section{INTRODUCTION}

The use of Information technology and communication in education worlds continuously developed in many strategies and patterns, which basically can be classified into e-learning system as a type of learning that use electronic tools and digital media, and learning mobile (M-learning) as a learning form which specifies using mobile communication tools and technology. The high rapid development of mobile tools, relatively be easy-used and the more affordable price to have them instead of Personal Computer tools which were pushed factors that brought more opportunities' expansion of using or applying the mobile learning as a new trend in studying, that forms learning paradigma that could be done in where ever and whenever.

Mobile learning or M-learning is a learning that uses telephone equipment or PDA as an infrastructure to do a flexible learning. M-learning provides more opportunities to collaborate and interact in informal way amongst the learners. M-learning is one of some alternative types potentially expanding the education access. However, there have not yet much information about the use of mobile devices, especially cellular phone, as a media learning. That is considerably regretted since there have already been in a high level of ownership and usages of cellular phones were less motivated to use it for education purpose.

Universitas Terbuka (UT) is an educational institution that applies a long-distance learning and uses information technology as one of learning media. In its learning process, students are expected to be independent learners through printed modules and other modules packaged in a form of $\mathrm{M}$ Learning. UT also provides teaching modules supported by the 
computer an audio/video program. Besides that, the students can follow tutorials both face-to-face session and online. On the contrary, most of the students only used the printed teaching modules, and a very few of them used other learning sources and owned the ability to use it.

This research showed that the resistance toward the changing concept, from conventional learning changed to be learning, could be understood, due to changing habits and confidence in teaching and substituting them with the new concept, that is learning through the internet. The result of this research indicated $70 \%$ until $90 \%$ teachers in Indonesia in term of utilizing the internet technology advances for the learning process and other activities were considered as technologically backward [2]. Meanwhile, $67.62 \%$ of UT students had status as teachers.(http://www.ut.ac.id/ut -in figures)

Related to the utilizing of M-learning as a part of information systems showed that the success of information system depends on the interest and satisfaction of the users. The users would feel interested and motivated to continuously use the information system if they felt the system gave the same result as the input provided [3]. The research of [4] found that an individual would have fairness motives and considerate his/her satisfaction level as fundamental.In order to reach that fairness, quality information, system and services were needed; therefore it was expected to have self-satisfaction achievement of the individual in using the information system [5].

Considering such background, this research was designed to scientifically discover about the variables that influence the behavior of SI Students of UT Economic Education Program towards M-learning. The variables that would be seen related to the students view the performance, social influence and selfconfidence and also the influence of using an M-learning.

This research used model UTAUT (Unified Theory of Acceptance and Use of Technology), [6] contained some variables such as performance expectancy and social influence. Besides, there was a significant variable toward user's motives in using information technology based on the research [7] was self-confidence. This model was used to know what influences factors were to the students in using internet technology especially M-learning.

\section{A. M-Learning (Mobile Learning)}

Mobile learning is a learning approach that involved mobile devices, such as handphone, PDA, Laptop and Tablet, PC, that a learner could access material, direction, and application related to the subject without inhibited by rooms and time, wherever and whenever they were. Ref. [8] defined "Mobile Learning was as:

“... The intersection of mobile computing and e-learning: accessible resources wherever you are, strong search capabilities, rich interaction, powerful support for effective learning, and performance-based assessment. E-learning independent of location in time or space."

M-learning gave benefit in providing material that could be accessed every time and provided an attractive visualization material. MLearning was a part of electronic-learning (elearning), therefore it was also part of distance learning (d- learning). One of the requirements in using mLearning was a capability to be connected to other devices, especially computer, to provide learning information and be able to realize bilateral communication between teacher and the learner. M-learning was a unique learning since a learner could access learning material, direction, and application related to the learning, wherever and whenever the learners were. This could attract the attention to the learning material, made a pervasive learning, and also increased the motivation to learn for a long life learning. Besides, if it was compared to conventional learning, mLearning gave more chances to have direct collaboration and interaction in an informal way amongst the learners.

The advantages M-Learning compared to other learning could be seen from its ability/advantages, such as (1) to be used at wherever and whenever, (2) most of the mobile devices were relatively cheaper price than the price of PC desktop (30 the tools size was smaller and lighter than PC desktop and (4) possibly could take more learner participating since $\mathrm{M}$ Learning utilizes the technology that usually used in daily life.

\section{B. M-Learning in Education}

One of the developing applications of knowledge and technology in the educational world is utilizing the internet. Today internet, according to [9] had been a reliable communication infrastructure and very useful for the importance of the researchers, teachers, and students, therefore it had to be understood by all teachers in learning activities. One of the facilities could be used in applicating internet was using M-Learning. The learning process goes beyond the classroom (global and long life education. In developed countries, commonly the price of technology equipment such as hand phone, iPad, PDA are cheaper than Computer Desktop [10].

M-Learning projects in Europe is similar to Project of Leonardo da Vinci" and IST FP5 in Europe. Project Uni Wap showed that mLearning became more important in the education world. Mobile Learning was a step ahead in developing electronic learning (e-learning). Since the communication tools resulted in easy transferred, the educational experts tried to take an initiative to apply the use of that tools in teaching and learning [10]. Some researchers of M-learning also showed that mobile equipment gave possibility for the students to get information, confirmed their tasks in wider scope and functioned more impressive in some situations that needed cooperation

\section{Variables of Model UTAUT in using Technology}

Some literature had reviewed the use of behavior concepts in utilizing the information technology. Those theories were such Theory of Reasoned Action by, Theory of Planned Behavior [11]. Theory of The Diffusion of Innovation [12] and other theories. Those theories were showing some behavioral variables of individuals in using information technology.

Then variables that found in those theories, had been combined by other researchers. One of those researchers was [6] who created UTAUT model (Unified Theory of Acceptance and Use of Technology) which was a combined theory of at least 6 theories that had been showed before. Variables that had 
been created in UTAUT were (1) variable of expectation toward performance, (2) Expectation towards the effort, (3) social influences and (4) conditions that facilitated it.[6]. Besides that, self confident variables, worries and attitude toward the use of technology, had been considered influence significantly in creating the intention to use the information technology as the research of [7] and [14] who placed it as an adequate influential variable at the intention of the use of technology, although in [6] found that those three variables had insignificant influences when they were applied in another research setting.

\section{Expectation toward performance}

Expectation toward performance was a level confident for the individual, which by using that system individual will improve his performance [6]. Expectation variable towards performance was arranged by using the construct of perceived usefulness) that came from Technology Acceptance Model Theory [14] relative advantage at Innovative Diffusion Theory [13] and outcome expectation of Social Cognitive Theory.

Contructof the use of perception, at the beginning, was appeared in Technology Reception Model Theory [14]. Definition of this construct is the level of confidence of the individual that by using a system made he/she improving his/her performance [14]. A system would have a highly useful perception if the user was confident that the existence of the system had positive relations with the increasing performance [14].

Construct that was built, then was a relative advantage construct that was a level of individual perception when using an innovation would affect into a better condition, instead of using no innovative system [13]. Beside that [14] connecting the relative advantage with the improving capabilities that was the more increasing capabilities of the individual when using the system, the more relative advantage he/she would get.

The research conducted by [15] Social Cognitive Theory) formed the third construct, which was expected outcome. This construct definition was the expectation to be achieved through increasing performance (efficiency and effectivity) and image changes or status after using the technology [15]. This construct appeared when an individual started finding difficulties in connecting between expectations to be achieved while using the system with the gained result.

Those third constructs discussed individual expectations when using a system, that their main objectives were improving the individual performance. Those constructs could not be separated, since an individual was going to use the system, the use of the system would be perceived beforehand, whether the relative advantages and outcomes would be appropriated with an individual perception itself, therefore the system would tend to be used.

\section{E. Social Influences}

Social influences would always appear when an individual behaved. Related to the use of information technology, [6] stated that social influences were perceptions of other persons surrounding the user. That surrounding peoples suggested the user use the information technology in his/her works.
Ref. [12] stated that subjective norm was an individual perception that important persons existed in his surrounding suggested to him to do or not to do a behavior action in using a system. Someone would consider this construct in his behavior when he was fewer experienced in using the system, so the suggestion of others would influence his behavior [16].

The next construct was social factors. This construct was appeared by [17] in his research regarding Information Technology useful Model. Social factor was the appeared factor when someone did an internalized process with people in his surroundings. (Usually was a group of people who had been his references in his behavior), then he made an approval to do something with those persons in a specific social situation [17]. Furthermore, when someone behaved in his life, he was much influenced by norms, rules, and values that had to be obeyed, therefore he often much depended on influences of his environments [17]). Construct of subjective norms and social factors together formed social influence variable since every individual in his behaves in his social life must be influenced by social factors of his environments, therefore his behavior often changed according to influences of his social environment. That social factor was poured in subjective norms of the society as consideration of his behavior.

\section{F. Self-Confident}

Self-confident is an individual decision that was made to show abilities and maturities of an individual in doing actions in a situation which supports [3]. Based on research of [18], explained that the higher of the confident level of himself, then the more increasing the intention of an individual to do the system. Furthermore, [15] also conducted a study on selfconfident, and found that self-confident both directly and indirectly influence the usage, This was because of the available paradigm that self-confident could not be measured in general would be the same in every situation, but actually was influenced by its specific situation [3].

\section{G. M-Learning Usage Behaviour}

Behaviour was a real action that was done [11]. This activity was done since an individual had the willingness or intention to do the actions [19]. Furthermore, in research of information system, behavior was an actual usage, but it was a very limited time of observation towards an individual. Szajna suggested that the real usage was changed into self-reported usage [20]. The behavioral measurement of an individual with using a variable of self-reported usage was marked by items of technology usage frequencies by the individual.

\section{H. Correlation between Variables and Hipotesa Development}

In general, Information Technology User expected that the increasing relative advantages and conformity with the output expectation would increase the intention to behave in using that technology [6]. This happened since there was a tendency to perceive the benefits before using the system, considered the relative advantage and the output, if they were appropriated with what an individual perceived, then the system would tend to be used.

The expectation on performance, in general, was connected with the students' expectation on output that was related to the work, completing the tasks, and extrinsic rewards [1], [6]. 
Based on that framework of thinking, the developed hypothesis in this research are:

H1: There is a significant correlation between expectations on performance after using M-Learning with the intention to use M-Learning on students.

The second variable is a social influence. In connection with mLearning information technology usage, [6] stated that social influence was the perception of others people surrounding whom considerately important person perceived by the user/ these people suggested the user to use this information technology in his works.

When faced with something new, someone tent to have support from another person [6]. This happened since every individual in his behaves in social life must be influenced by social factors from his environment, therefore individual behavior often changed according to the influence of his social environment. These Social factors were poured in subjective norms in society as individual consideration to behave.

The second hypothesis is $\mathrm{H} 2$ : There is a significant correlation between social influences in M-Learning usage with the intention to use mLearning on the student.

The third variable is self-convincing/confident, which is an individual decision that was made to show abilities and maturities of an individual in doing actions in a prospective situation [3]. The higher of the confident level of himself, the more increasing the intention of an individual to use the system. Furthermore, [15] also conducted a study on selfconvincing and found that self-convincing had an actual direct impact on influencing the usage.

Self confidentce commonly connected with the output is related to the work, completing the tasks and extrinsic rewards [1], [6], since the more confident of an individual in using a technology, so the work output, the speed in completing tasks and extrinsic rewards toward his work would be increased. Therefore, the third hypothesis was developed.

H3: There is a significant correlation between selfconvincing/confidence M-learning usages with the intention to use mLearning, especially by students.

Behaviour is a real action or activity conducted by an individual since an individual has a will or intention to do it, therefore researcher suspects that an intention to use will significantly influence on a sustainable technology usage, then hypothesis appeared, H4: Intention to use mLearning will influence significantly on mLearning usage behavior.

\section{Model tested in this research was following,}

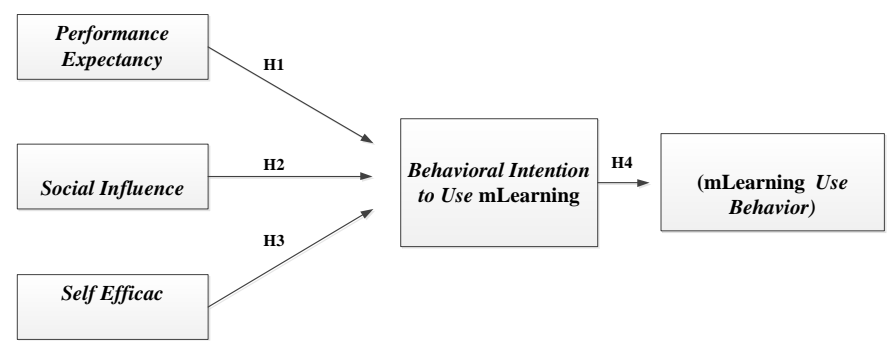

Fig. 1. Influences between Variables

\section{METHODE}

In this research, the method used is survey research method and be classified as quantitative research, since its data can be classified, concrete, observable and measurable. Variables that used in this research were expectation towards performance (X1), Social influences (X2), Self /confident (X3) and Mobile Learning usage Behaviour (Y)

\section{A. Population and Sample}

Population in this research is S1 Students of Economic Education in throughout Indonesia, who follow online tutorial services. The sample is taken by systematic sampling, classified by sampling stratification based on the UPBJJ location. The sample was taken in every selected region, done with the representation of respondents who active in an online tutorial. The total sample is 148 students who represented UPBJJ population.

\section{B. Technic of Data Analysis}

Data Analysis was done with correlation test and regression by using Path Analysis. Previously, normality test was done for every variable. Data analysis was done at significant level of 0.05

\section{RESULT AND DISCUSSION}

\section{A. Result of Validity Test and Reliability}

Validity and Reliability Test at every variable, obtained value of $r$ counting or correlation was bigger than $r$ table for $\mathrm{u}=30$ with alpha $5 \%$ amounts 0.361 , therefore all questions are valid. Alpha Cronbach value was bigger than cut value 0.70 , and then it was said reliable.

TABLE 1. RESULT OF CORRELATION AMONG VARIABLES

\begin{tabular}{|c|l|l|l|l|l|l|}
\hline \multicolumn{2}{|c|}{ Correlations } & $\mathrm{X} 1$ & $\mathrm{X} 2$ & $\mathrm{X} 3$ & $\mathrm{Y} 1$ & $\mathrm{Y} 2$ \\
\hline $\mathrm{X} 1$ & Pearson Correlation & & & & & \\
\hline & Sig. (2-tailed) & & & & & \\
\hline $\mathrm{X} 2$ & Pearson Correlation & $0.412^{* *}$ & 1 & & & \\
\hline & Sig. (2-tailed) & 0.008 & & & & \\
\hline $\mathrm{X} 3$ & Pearson Correlation & $0.393^{*}$ & $0.625^{* *}$ & & & \\
\hline & Sig. (2-tailed) & 0.012 & 0.000 & & & \\
\hline Y1 & Pearson Correlation & $0.549^{* *}$ & $0.641^{* *}$ & $0.651^{* *}$ & 1 & \\
\hline & Sig. (2-tailed) & 0.000 & 0.000 & 0.000 & & \\
\hline Y2 & Pearson Correlation & 0.221 & $0.338^{*}$ & 0.163 & $0.316^{*}$ & 1 \\
\hline & Sig. (2-tailed) & 0.170 & 0.033 & 0.313 & 0.047 & \\
\hline$* *$ & Correlation is significant at the 0.01 level (2-tailed). & & \\
\hline$*$ & Correlation is significant at the 0.05 level (2-tailed). & & \\
\hline
\end{tabular}

\section{B. Substructural Model 1}

TABLE 1I. RESULT OF STATISTIC WORK OF MODEL 1 (ANOVA) MODEL 1

${ }_{A N O V A}{ }^{b}$

\begin{tabular}{|c|c|c|c|c|c|c|}
\hline & & $\begin{array}{c}\text { Sum of } \\
\text { Squares }\end{array}$ & df & Mean Square & $\mathrm{F}$ & Sig. \\
\hline \multirow[t]{3}{*}{1} & Regression & 1438,222 & 3 & 479,407 & 16,559 &, $000^{\mathrm{a}}$ \\
\hline & Residual & 1042,264 & 36 & 28,952 & & \\
\hline & Total & 2480,486 & 39 & & & \\
\hline
\end{tabular}

b. Dependent Variable: $Y 1$ 
TABLE 1II. RESULT OF STATISTIC WORK OF MODEL 1 (COEFFICINET)

\begin{tabular}{|c|c|c|c|c|c|c|}
\hline \multicolumn{7}{|c|}{ Co e efficie nts $^{a}$} \\
\hline & & \multicolumn{2}{|c|}{$\begin{array}{l}\text { Unstandardized } \\
\text { Coefficients }\end{array}$} & \multirow{2}{*}{$\begin{array}{c}\begin{array}{c}\text { Standardized } \\
\text { Coefficients }\end{array} \\
\text { Beta }\end{array}$} & \multirow[b]{2}{*}{$t$} & \multirow[b]{2}{*}{ Sig. } \\
\hline \multicolumn{2}{|c|}{ Model } & $B$ & Std. Error & & & \\
\hline 1 & (Constant) & 23,919 & 8,865 & & 2,698 &, 011 \\
\hline & $\mathrm{X} 1$ & ,253 & 107 & 286 & 2,372 & ,023 \\
\hline & X2 & 260 & 121 & ,306 & 2,151 & ,038 \\
\hline & X3 & 249 & 101 & ,347 & 2,463 &, 019 \\
\hline
\end{tabular}

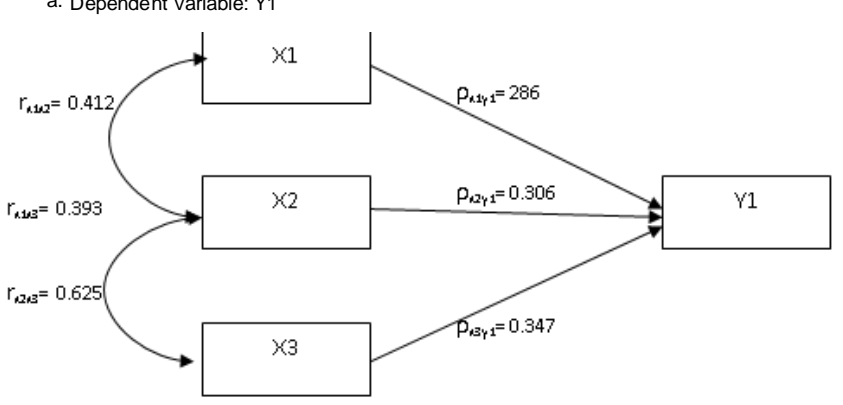

Fig. 2. Structural Model 1

Based on the result of the data proceed and model hypothesis, the explanation was following:

H1: There was a significant correlation between expectation toward performance after using M-learning with the intention of students to use M-Learning.

The result of processed data was a coefficient session for $\mathrm{X} 1$ to $\mathrm{Y}$ is mounted 0.286 with probability values $(0.023)$ where probability value was smaller than alpha $5 \%$, meaning that there was significant correlation and positive between expectations toward performance after using M-Learning with the intention to use it on students.

H2. There was significant correlation between social influences in learning usage with the intention to use MLearning on students

The result of data processed showed that coefficient for X2 to Y mounted 0.306 with the probabilities value $(0,038)$ where probability value small big from alpha $5 \%$, meant that there was a significant and positive relationship between social influence in learning usage with the intention to use MLearning on students.

$\mathrm{H}$ : There was a significant correlation between selfefficacy in e-Learning usage with the intention to use Learning, especially for students.

The data showed that coefficient for X3to $\mathrm{Y}$ amounted 0.347 with small big probabilities' value of Alpha 5\%, meaning that there was a significant and positive correlation between self-efficacy in mLearning usage with the intention to use mLearning, especially for the students.

\section{Substructural Model 2}

TABLE $1 \mathrm{~V}$. RESULT OF STATISTIC WORK OF MODEL 2 (COEFFICINET)

\begin{tabular}{|c|c|c|c|c|c|c|}
\hline \multicolumn{7}{|c|}{ Coe efficie nts ${ }^{a}$} \\
\hline \multirow{2}{*}{\multicolumn{2}{|c|}{ Model }} & \multicolumn{2}{|c|}{$\begin{array}{l}\text { Unstandardized } \\
\text { Coefficients }\end{array}$} & \multirow{2}{*}{$\begin{array}{c}\text { Standardized } \\
\text { Coefficients } \\
\text { Beta }\end{array}$} & \multirow[b]{2}{*}{$\mathrm{t}$} & \multirow[b]{2}{*}{ Sig. } \\
\hline & & $B$ & Std. Error & & & \\
\hline 1 & (Constant) & $\begin{array}{l}-39,370 \\
\end{array}$ & 54,728 & &,- 719 & ,476 \\
\hline & Y1 & 1,376 & ,671 & ,316 & 2,051 & ,047 \\
\hline
\end{tabular}

a. Dependent Variable: Y2

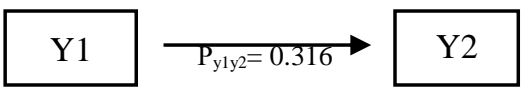

H4 : The intention to use M-Learning would influence significantly toward the behavior of M-Learning usage.

The analyzed data showed coefficient for $Y_{1}$ to $Y_{2}$ amounted 0.316 with probabilities value $(0,047)$ where probabilities value was smaller than alpha $5 \%$, meant that there was no significant and positive correlation between intention to use mLearning towards mLearning usage behavior.

Therefore, the result of path analysis of combining substructural 1 and substructural 2 model were following:

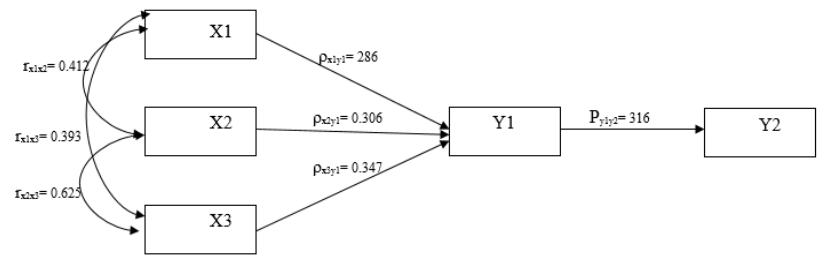

Fig. 3. Structural 2 Model

. This research showed that variable that influences the intention to use M-Learning on students S1 Economic Education Program of Universitas Terbuka was expectation towards performance after mLearning usage. It meant that students of UT hoped that there would be improving performance after they use M-Learning.

Beside that social influence, variables were such as friends, relatives and closed people around the students gave effect on intention to use M-Learning. While students' social environment perceived M-learning usage well, would bring intention to use M-Learning. Other variables that significantly affected on intention to use learning were self-efficacy, and the intention to use M-learning would not significantly affect the behavior of M-Learning usage. The students who had the intention to use M-learning would not be continuous and sustainable in using M-learning on their own learning activities.

\section{CONCLUSION}

\section{A. Conclusion}

Based on the research result, the conclusions were gained as follows: 
- There was a significant correlation between expectation toward performance after $m$ learning usage with the intention to use learning on students.

- There was a significant correlation between social influence in M-Learning usage with the intention to use M-Learning on the students

- There was a significant correlation between the selfefficacy of M-Learning usage with the intention to use M-Learning, especially on the students.

\section{B. Suggestions.}

This research suggested that the quality improvement $t$ of UT learning absolutely necessary to increase students' interest in using M-Learning. This quality improvement would effect on the willingness of the students to use non-printed teaching material as one of learning aid. This effort was expected to improve the students' ability in learning based on technology use and finally, it would increase students' capacity on longdistance learning program.

\section{REFERENCES}

[1] Andiani, et.al, "Layanan Bantuan Belajar \& Pemanfaatan Sumber Belajar dalam Sistem Pendidikan Terbuka \& Jarak Jauh,"simpen.lppm.ut.ac.id/pdffiles/11_Layanan\%20Bantuan\%20Belaja $r$.

[2] Sunarno, "Isu-isu Terkini Guru dalam Pemanfaatan Teknologi Informasi dan Komunikasi," 2008, http://Sunarnomip.staff.ugm.ac.id.

[3] Bandura, A., Adams, N. E., and Beyer. "Cognitive Processes Mediating Behavioral Change," Journal of Personality and Social Psychology (35:3), 1977. pp. 125-139.

[4] Martinez-Tur, V., Peiro, J. M., Ramos, J., and Moliner, C. . "Justice PerceptionsasPredictorsof Customer Satisfaction: The Impact of Distributive, Procedural, and Interactional Justice," Journal of Applied Social Psychology (36:1), 2006, pp. 100-119.

[5] William H. DeLone and Ephraim R. McLean, "Measuring e-Commerce Success: Applying the DeLone \& McLean Information Systems Success Model," International Journal of Electronic Commerce Vol. 9, Iss. 1,2004 .
[6] Venkatesh, V., Morris, M. G., Davis, G. B., and Davis, F. D. "User Acceptance of Information Technology: Toward a Unified View," MIS Quarterly (27:3), 2003, pp. 425-478.

[7] Compeau. D. R., and Higgins, C. A.. "Computer Self-Efficacy: Development of a Measure and Initial Test", MIS Quarterly (19:2), 1995, pp. 189-211.

[8] Quinn, C, "e-Learning. Mobile, Wireless, In-Your-Pocket Learning,"Linezine.Fall 2000, Available at http://www.linezine.com/2.1/features/cqmmwiyp.htm.

[9] Munir, Kurikulum Berbasis Teknologi Informasidan Komunikasi. Bandung: Alfabeta, 2008.

[10] https://neozonk.wordpress.com/2012/09/18/penggunaan-mobilelearning-dalam-teknologi-pembelajaran/

[11] Fishbein, M., dan Ajzen, I. Belief, Attitude. Intention and Behavior: An introduction to Theory and Research. Addison-Wesley: Reading, MA. (1975).

[12] Azjen, I. (1991). The theory of planned behavior. Organisational Behaviour and Human Decision Processes, 50, 179-211.

[13] Moore, G. C, dan Benbasat, I., "Development of an Instrument to Measure the Perceptions of Adopting an Information Technology Innovation," Information Systems Research (2:3), 1991, pp. 192-222.

[14] Davis, F.D., Bagozzi, R.P. dan Warshaw, P.R., "User Acceptance of Computer Technology: A Comparison of Two Theoretical Models", Management Science (35:8), August,1989, pp. 982-1003.

[15] Compeau, D. R., Higgins, C. A., and Huff, S., "Social Cognitive Theory and Individual Reactions to Computing Technology: A Longitudinal Study," MIS Quarterly (23:2), 1999, pp. 145-158.

[16] Hartwick, J., dan Barki, H., "Explaining the Role of User Participation in Information System Use," Management Science (40 A), 1994, pp. 40465

[17] Thompson, R. L., Higgins, C. A., and Howell, J. M.,"Personal Computing: Towards a Conceptual Model of Utilization," MIS Quarterly (3:4), 1991, pp. 125-143.

[18] Taylor, S., dan Todd, P. A., "Assessing IT Usage: The Role of Prior Experience," MIS Quarterly (19:2), 1995, pp. 561-570.

[19] Sheppard, B. H., Hartwick, J., dan Warshaw, P. R., "The Theory of Reasoned Action: A Meta-Analysis of Past Research with Recommendations for Modifications and Future Research". Journal of Consumer Research (15:3). 1988, pp. 325-343

[20] Szajna, B., "Empirical Evaluation of The Revised Technology Acceptance Model," Management Science. (42:1), 1996, pp. 85-92 